\title{
PENGARUH STRATEGI QUANTUM LEARNING TERHADAP HASIL BELAJAR MENULIS TEKS TANGGAPAN DESKRIPTIF
}

\author{
Citra Indraswari*, Kurnia ${ }^{2}$, Suhaebah Nur ${ }^{3}$
}

\begin{abstract}
In the implementation of the learning ability to write descriptive response text. lack of use of a variety of strategies causes students to feel bored following learning. The reality happened to students of class VII $A$ as an experimental (group) class, and class VII B as a class (group) control of 5 Wonomulyo State Junior High School in Polewali Mandar District. The population of this study was the entire class VII of the 5th Junior High School of Wonomulyo, Polewali Mandar Regency, totaling 176 people, who were placed in five classes. The sample in this study were 2 classes randomly selected from 6 classes based on the results of simple random sampling and prior to determining the sample beforehand the initial test (Pre-test) was carried out to all participants in class VII of the 5 Wonomulyo Junior High School and the class that obtained grades the same or almost the same average is taken as an assessment class. This assessment will use 1 experimental class and 1 control class. Based on the results of simple random sampling, class VII $A$ as an experimental class, and class VII B as a control class. The data analysis technique used is descriptive statistical analysis and inferential statistical analysis. The inferential statistical test results show that the value of $t$ count at equal variances assumed $=2.034 \mathrm{df}=54$, and obtained t table $=2.004$ so that $t$ count $=2.034>t$ table $=2.004$ and significance $0.004<0.05$. Then $\mathrm{HO}$ is rejected and $\mathrm{H} 1$ is accepted. Thus it can be concluded that quantum learning strategies affect learning to write descriptive response texts for grade VII students of Wonomulyo Polewali Mandar 5 Junior High School.
\end{abstract}

Keywords: Influence, Quantum Learning Strategy, Writing Descriptive Response Text

*) Prodi Pend. Bahasa Indonesia, Universitas Al Asyariah Mandar email: citra indraswari@yahoo.com

${ }^{2}$ Prodi Pend. Bahasa Indonesia, Universitas Al Asyariah Mandar email : sastra_kurnia@yahoo.com 


\section{PENDAHULUAN}

Pendidikan adalah salah satu bentuk perwujudan kebudayaan manusia yang dinamis dan sarat perkembangan. Oleh Karena itu, perubahan atau perkembangan pendidikan adalah hal yang memang seharusnya terjadi sejalan dengan perubahan budaya kehidupan. Perubahan dalam arti perkembangan pada semua tingkat perlu terus-menerus dilakukan sebagai antisipasi kegiatan masa depan (Trianto, 2010: 1).

Bahasa Indonesia adalah bahasa yang terpenting di kawasan republik ini. Pentingnya peran bahasa itu antara lain bersumber pada ikrar ketiga sumpah pemuda 1928 yang berbunyi: "Kami poetra dan poeteri Indonesia mandjoendjoeng bahasa persatoen, bahasa Indonesia" dan pada undang-undang dasar kita yang di dalamnya tercantum pasal khusus yang menyatakan bahwa: "bahasa Negara ialah bahasa Indonesia". Namun, di samping itu masih ada beberapa alasan lain mengapa bahasa Indonesia menduduki tempat terkemuka di antara beratus-ratus bahasa Nusantara yang masing-masing amat penting bagi penuturnya sebagai bahasa ibu.

Kemampuan berbahasa adalah kemampuan menggunakan bahasa. Kemampuan itu terlihat di dalam empat aspek keterampilan. Keempat aspek itu adalah mendengarkan, berbicara, membaca, dan menulis. Seseorang yang ingin mengembangkan kemampuan berbicara dan menulis, mestilah banyak mendengar dan membaca. Oleh karena itu, dengan mendengar dan membaca akan diperoleh informasi untuk dibicarakan dan dituliskan. Menulis termasuk aspek kegiatan berbahasa yang dianggap sulit. Hal itu dikeluhkan oleh banyak orang. Peserta didik di pendidikan dasar dan menengah, mahasiswa di pendidikan tinggi, dan bahkan orang-orang yang sudah menamatkan perguruan tinggi pun mengeluhkan sulitnya menulis.

Pada pelaksanaan pembelajaran kemampuan menulis teks tanggapan deskriptif. kurangnya penggunaan strategi yang variatif menyebabkan peserta didik merasa jenuh mengikuti pembelajaran. Kenyataan terjadi pada peserta didik kelas VII A sebagai kelas (kelompok) eksperimen, dan kelas VII B sebagai kelas (kelompok) kontrol SMP Negeri 5 Wonomulyo Kabupaten Polewali Mandar. Berdasarkan hasil survei dan wawancara dengan guru bahasa dan sastra Indonesia kelas VII SMP Negeri 5 Wonomulyo terhadap pembelajaran menulis adalah guru sulit membangkitkan minat belajar kepada peserta didik. Rendahnya pemahaman peserta didik terhadap pembelajaran mengidentifikasi kriteria penulisan teks tanggapan deskriptif secara baik. Dalam proses menulis teks terapan deskriptif guru sering mengulangi pelajaran beberapa kali. Ini di buktikan oleh nilai semester peserta didik yang tidak mencapai KKM. 
Melihat kondisi tersebut, akhirnya peneliti berusaha memberikan solusi alternatif, yaitu penggunaan Strategi Quantum Learning yang tepat agar dapat memperbaiki dan meningkatkan keterampilan siswa dalam menulis. Selain itu cara mengajar guru harus menggunakan teknik pembelajaran yang bervariasi dan kreatif. Merujuk pada segala permasalahan di atas, peneliti membuat solusi. Penelitian tentang peningkatan keterampilan menulis dengan menggunakan Strategi Quantum Learning dilakukan karena dengan mendekatkan objek belajar dengan siswa akan lebih memudahkan siswa untuk menulis dengan baik. Berdasarkan penjelasan tersebut maka tujuan penelitian ini adalah untuk mengetahui pengaruh strategi Quantum Learning terhadap kemampuan menulis teks tanggapan deskriptif peserta didik kelas SMP Negeri 5 Wonomulyo.

Berdasarkan penjelasan tersebut maka tujuan penelitian ini adalah untuk mengetahui pengaruh strategi Quantum Learning terhadap kemampuan menulis teks tanggapan deskriptif peserta didik kelas SMP Negeri 5 Wonomulyo.

\section{Keterampilan Berbahasa}

Keterampilan berbahasa terbagi menjadi empat aspek, yaitu menyimak, berbicara, membaca, dan menulis. Keempat aspek tersebut berkaitan antara satu dengan lainnya. Menyimak dapat didefinisikan suatu aktivitas yang mencakup kegiatan mendengar bunyi bahasa, mengidentifikasi, menilik dan mereaksi atas makna yang terkandung dalam bahan menyimak. (Tarigan, 2008: 31). Pendapat Tarigan (2008: 27), pada kegiatan mendengarkan mungkin si pendengar tidak memahami apa yang didengar. Pada kegiatan mendengarkan sudah ada unsur kesengajaan, tetapi belum diikuti unsur pemahaman karena itu belum menjadi tujuan.

Selanjutnya, berbicara merupakan proses berbahasa lisan untuk mengekspresikan pikiran dan perasaan, merefleksikan pengalaman, dan berbagi informasi. Ide merupakan esensi dari apa yang kita bicarakan dan kata-kata merupakan untuk mengekspresikannya. Berbicara merupakan proses yang kompleks karena melibatkan berpikir, bahasa, dan keterampilan sosial. Menurut Mudini dan Salamat (2009: 3) mengemukakan pengertian berbicara sebagai keterampilan menyampaikan pesan melalui bahasa lisan sebagai aktivitas untuk menyampaikan gagasan yang disusun serta dikembangkan sesuai dengan kebutuhan penyimak. Dengan berbicara seseorang berusaha untuk mengungkapkan pikiran dan perasaannya kepada orang lain secara lisan. Tanpa usaha untuk mengungkapkan dirinya, orang lain tidak akan mengetahui apa yang dipikirkan dan dirasakannya. Ketika kita tanpa bicara, orang tidak akan dapat saling berinteraksi dengan sesamanya dan seakan terkucilkan dari lingkungannya. Untuk berkomunikasi dengan sesamanya manusia lebih sering 
menggunakan bahasa lisan daripada bahasa tulis. Oleh karena itu, keterampilan berbicara menjadi salah satu hal terpenting dalam kehidupan manusia.

Aspek keterampilan berbahasa selanjutnya adalah membaca. Membaca adalah proses memahami pesan tertulis yang menggunakan bahasa tertentu yang disampaikan oleh penulis kepada pembacanya. Menurut Anderson, (dalam Alek dan Achmad H.P, 2010: 74) membaca ialah suatu proses untuk memahami yang tersirat dalam yang tersurat, melihat pikiran yang terkandung di dalam kata-kata yang tertulis. Membaca ialah suatu proses yang dilakukan dan digunakan oleh pembaca untuk memperoleh pesan yang hendak disampaikan oleh penulis melalui media kata-kata/bahasa tulis. Tarigan, (dalam Alek dan Achmad H.P, 2010: 74).

Aspek keterampilan berbahasa yang terakhir adalah menulis. Menulis ialah sebuah kegiatan menuangkan pikiran, gagasan dan perasaan seseorang yang diungkapkan dalam bahasa tulis. Dalam pengertian yang lain, menulis adalah kegiatan untuk menyatakan pikiran dan perasaan dalam bentuk tulisan yang diharapkan dapat dipahami oleh pembaca dan berfungsi sebagai alat komunikasi secara tidak langsung.

Menulis seperti juga halnya ketiga keterampilan berbahasa lainnya, merupakan suatu proses perkembangan. Menulis menuntut pengalaman, waktu, kesempatan, latihan, keterampilan-keterampilan khusus, dan pengajaran langsung menjadi seorang penulis. Menurut gagasan-gagasan yang tersusun secara logis, diekspresikan dengan jelas, dan ditata secara menarik. Selanjutnya menuntut penelitian yang terperinci, observasi yang saksama, pembedaan yang tepat dalam pemilihan judul, bentuk dan gaya. Secara singkat dapat dikemukakan bahwa tulisan dibuat untuk dibaca, tulisan didasarkan pada pengalaman, tulisan ditingkatkan melalui latihan terpimpin, dalam tulisan makna menggantikan bentuk dan kegiatan-kegiatan bahasa lisan hendaklah mendahului kegiatan menulis (Logan dalam Tarigan 2008: 9).

\section{Menulis}

Menulis merupakan salah satu keterampilan berbahasa yang dimiliki seseorang untuk mengungkapkan ide, pikiran, gagasan, atau perasaan secara tertulis dengan menggunakan bahasa tulis sebagai medianya. Kegiatan menulis melibatkan beberapa aspek yaitu penulis, isi tulisan, media, dan pembaca. Dalam Kamus Besar Bahasa Indonesia dijelaskan bahwa menulis adalah melahirkan pikiran atau perasaan (seperti mengarang dan membuat surat) dengan tulisan (Depdikbud, 2008: 1497). Menulis merupakan suatu kegiatan komunikasi berupa penyampaian pesan (informasi) secara tertulis kepada pihak 
lain dengan menggunakan bahasa tulis sebagai alat atau medianya (Dalman, 2014:3).

Menulis berarti menurunkan atau melukiskan lambang-lambang grafik suatu bahasa yang dipahami oleh seseorang, sehingga orang lain dapat membaca dan memahami lambang-lambang grafik tersebut. Menulis berbeda dengan melukis atau menggambar. Gambar atau lukisan dapat menyampaikan makna, tetapi tidak menggambarkan kesatuan-kesatuan bahasa. Menulis merupakan suatu representasi bagian dari kesatuan-kesatuan ekspresi bahasa. Melukis huruf bukanlah menulis sebab dengan kegiatan menulis menuntut pengetahuan tentang kaidah-kaidah penulisan Weiss (dalam Salam, 2009:39).

Teks

Dalam teori bahasa apa yang dinamakan teks tak lebih dari himpunan huruf yang membentuk kata dan kalimat yang dirangkai dengan sistem tanda yang disepakati oleh masyarakat sehingga sebuah teks ketika dibaca bisa mengungkapkan makna yang dikandungnya (Budiman, 2009:54). Teks bisa berupa kata, kalimat, paragraf, atau wacana, yang memiliki karakteristik tertentu secara konvensional diterima, secara kognitif dipahami, yang kemudian karakteristik teks itu sendiri disebut tekstur (Zainurrahman, 2011:128).

Teks bila kita tuliskan tampak seakan-akan terdiri dari kata-kata dan kalimat-kalimat, namun sesungguhnya terdiri dari makna-makna. Maknamakna itu harus diungkapkan atau dikodekan dalam kata-kata dan struktur, selanjutnya dapat diungkapkan kembali dalam bunyi-bunyi atau lambanglambang tulis. Teks itu harus dikodekan dalam sesuatu untuk dapat dikomunikasikan; tetapi sebagai sesuatu yang mandiri, teks itu pada dasarnya adalah satuan makna. Teks bukan sesuatu yang dapat diberi batasan seperti sejenis kalimat, melainkan lebih besar (Halliday, 1994: 14).

Beberapa ahli bahasa mengklasifikasikan teks secara beragam. Gorys Keraf (1982:3-4) mengklasifikasikan jenis teks wacana menjadi lima macam, yaitu tanggapan deskriptif, argumentasi, deskriptif, narasi, dan persuasi. Sementara itu, Weaver dan Morris (dalam Mahmudi, 2013:19) mengklasifikasikan jenis tulisan menjadi empat, yaitu narasi, deskriptif, tanggapan deskriptif, dan argumentasi. Pendapat tersebut diperkuat oleh Brooks dan Waren (dalam Mahmudi, 2013:19) dengan empat jenis wacana, yaitu tanggapan deskriptif, persuasi, argumentasi, dan deskriptif.

Teks Tanggapan Deskriptif

Deskriptif adalah paragraf yang berisi penggambaran suatu objek, tempat atau peristiwa tertentu kepada pembaca secara jelas dan terperinci sehingga pembaca seolah-olah melihat dan merasakan sendiri apa yang 
dideskripsikan oleh penulis. Jadi, berdasarkan uraian di atas deskriptif adalah gambaran mengenai suatu hal yang dilukiskan dengan kondisi atau keadaan yang sebenarnya berisi penggambaran suatu objek, tempat atau peristiwa tertentu sehingga dapat dirasakan, dilihat, dicium dan didengar oleh pembaca.

Struktur teks membentuk struktur berpikir sehingga setiap penguasaan jenis teks tertentu siswa akan memiliki keterampilan berpikir sesuai dengan struktur teks yang dikuasainya. Dengan berbagai macam teks yang sudah dikuasainya, berarti siswa akan mampu memiliki berbagai struktur berpikir, bahkan satu topik tertentu dapat disajikan dalam jenis teks yang berbeda dan tentunya dengan struktur berpikir yang berbeda (Kemendikbud, 2013: 3). Adapun struktur teks tanggapan deksripsi, yaitu identifikasi, klasifikasi/definisi, dan deskripsi bagian.

\section{Strategi Quantum Learning}

Menurut De Porter (2009: 16), pembelajaran Quantum adalah "interaksiinteraksi yang mengubah energy menjadi cahaya". Semua kehidupan adalah energi. Dan tujuan belajar adaah meraih sebanyak mungkin cahaya, interaksi, hubungan, inspirasi agar menghasilkan energi cahaya. Dan menurut Arends (Trianto, 2007: 1). Pembelajaran Quantum adalah suatu perencanaan atau suatu pola yang digunakan sebagai pedoman dalam perencanaan atau suatu pola yang digunakan sebagai pedoman dalam merencanakan pembelajaran di kelas atau pembelajaran dalam tutorial. Sementara Saud (2010: 16) mendefinisikan bahwa pembelajaran Quantum mengonsep tentang "menata pentas lingkungan belajar yang tepat", maksudnya bagaimana upaya penataan situasi lingkungan belajar yang optimal baik secara fisik maupun mental. Dengan mengatur lingkungan belajar sedemikian rupa, peserta didik diharapkan mendapatkan langkah pertama yang efektif untuk mengatur pengalaman belajar.

Quantum merupakan pembelajaran yang dilaksanakan dengan proses yang benar-benar terencana dengan baik. Pembelajaran Quantum merupakan kiat, petunjuk, strategi,dan seluruh proses belajar yang dapat mempertajam pemahaman dan daya igat, serta membuat belajar sebagai suatu proses yang menyenangkan dan bermanfaat.

Pembelajaran Quantum sebagai salah satu model, strategi, dan pendekatan pembelajaran khususnya menyangkut keterampilan guru dalam merancang, mengembangkan, dan mengelola sistem pembelajaran menjadikan guru lebih kompeten dalam menciptakan suasana pembelajaran yang efektif, menggairahkan, dan memiliki keterampilan hidup. Dengan demikian model pembelajaran Quantum ini merupakan bentuk inovasi pengubahan bermacammacam interaksi yang ada di dalam dan di sekitar momen belajar. Interaksi- 
interaksi ini mencakup unsur-unsur belajar efektif yang mempengaruhi kesuksesan peserta didik dalam belajar. Proses interaksi yang dilakukan di dalam pembelajaran Quantum pada prinsipnya mengubah kemampuan dan bakat alamiah peserta didik menjadi cahaya yang akan bermanfaat bagi mereka sendiri dan bagi orang lain.

Model pembelajaran Quantum identik dengan sebuah simfoni dan pertunjukan musik. Maksudnya pembelajaran Quantum, memberdayakan seluruh potensi dan lingkungan belajar yang ada, sehingga proses belajar menjadi suatu yang menyenangkan dan bukan sebagai sesuatu yang memberatkan.

\section{METODE PENELITIAN}

Jenis penelitian ini adalah penelitian eksperimen yang membagi sampel ke dalam dua kelompok perlakuan, yaitu satu kelas sebagai kelompok eksperimen dan satu kelas sebagai kelas kontrol. Kelas eksperimen diajar dengan strategi Quantum Learning dan kelas pembanding (kontrol) diajar dengan metode konvensional (ceramah) pada peserta didik kelas VII SMP Negeri 5 Wonomulyo Kabupaten Polewali Mandar.

Desain penelitian yang digunakan dalam penelitian ini adalah desain penelitian yang bersifat eksperimental jenis desain Pre-test dan Post-test group. Penelitian ini merupakan penelitian eksperimen dan tes yang digunakan sebanyak 2 kali, yaitu Pre-tes (sebelum eksperimen) dan sebelumnya kegiatan Post-test (setelah eksperimen).

Pelaksanaan penelitian dilakukan sebanyak 4 kali pertemuan (1 kali pretest, 2 kali tatap muka dan 1 kali post-test) masing-masing kelompok dengan alokasi waktu $2 \times 45$ menit tiap pertemuan.

Penelitian ini dilaksanakan di SMP Negeri 5 Wonomulyo Adapun waktu penelitian ini dilakukan pada semester ganjil tahun pelajaran 2016/2017, yang dimulai pada bulan Agustus sampai September.

Populasi penelitian ini adalah keseluruhan kelas VII SMP Negeri 5 Wonomulyo Kabupaten Polewali Mandar. Sampel dalam penelitian ini adalah 2 kelas yang dipilih secara acak dari 6 kelas berdasarkan hasil sampling acak sederhana dan sebelum penentuan sampel terlebih dahulu dilakukan tes awal (Pre-test) kepada seluruh peserta didk kelas VII SMP Negeri 5 Wonomulyo dan kelas yang memperoleh nilai rata-rata yang sama atau hampir sama diambil sebagai kelas penilaian. Variabel yang dikaji dalam penelitian ini terdiri atas variabel bebas dan variabel terikat. Variabel bebas dalam penelitian ini adalah penggunaan strategi Quantum Learning pada kelas eksperimen dan metode 
konvensional pada kelas kontrol. Sedangkan variabel terikat adalah kemampuan peserta didik dalam menulis.

Variabel penelitian didefinisikan sebagai berikut.

1. Strategi Quantum Learning adalah cara-cara yang di pilih dan digunakan oleh seorang pengajar untuk menyampaikan materi pembelajaran sehingga akan memudahkan peserta didik menerima dan memahami materi pembelajaran

2. Kemampuan menulis teks tanggapan deskriptif adalah kesanggupan menuangkan ide/gagasan dalam bentuk penggambaran.

Instrumen yang digunakan dalam penelitian ini adalah berupa lembar tes, lembar observasi dan kuesioner. Teknik pengumpulan data dilakukan dengan menggunakan teknik tes dan nontes. Teknik analisis data yang digunakan pada peneliti ini adalah statistik deskriptif dan inferensial. Statistik deskriptif digunakan untuk mendeskripsikan variabel penelitian dalam bentuk rata-rata, standar deviasi, variansi, median, dan modus dari kedua kelas sedangkan statistik inferensial digunakan untuk menguji hipotesis penelitian. Uji hipotesis yang digunakan dalam penelitian ini adalah uji-t (t-test) untuk menguji signifikasi perbedaan mean dua kelompok data pada tarif signifikan 0,05.

a. Uji Normalitas

Rumus hipotesis sebagai berikut:

$\mathrm{H}_{0}$ : Data berdistribusi normal

$\mathrm{H}_{1}$ : Data tidak berdistribusi normal

Jika signifikansi $>0,05$, maka data berdistribusi normal dan jika Signifikansi $<0,05$, maka data tidak berdistribusi secara normal. Jadi, apa bila hasil uji normalitas data di peroleh signifikansi $>0,05$, maka $\mathrm{H}_{0}$ diterima dan apa bila hasil uji normalitas data diperoleh signifikansi $<0,05$ maka $\mathrm{H}_{0}$ ditolak.

b. Uji Homogenitas

Uji homogenitas dilakukan untuk mengetahui apakah sampel yang diteliti homogen atau tidak.

Rumusan hipotesis statistik yang digunakan adalah sebagai berikut.

$\mathrm{H}_{0}: \mu_{\mathrm{E}}=\mu_{\mathrm{K}}$

$\mathrm{H}_{1}: \mu \mathrm{E} \neq \mu_{\mathrm{K}}$

Keterangan:

$\mu_{\mathrm{E}}=$ Rata-rata nilai kelompok eksperimen

$\mu_{\mathrm{K}}=$ Rata-rata nilai kelompok kontrol

Kriteria pengujian berdasaran signifikansi:

- Jika signifikansi $>0,05$, maka $\mathrm{H}_{0}$ diterima

- Jika signifikansi $<0,05$ maka $\mathrm{H}_{0}$ ditolak 
Jadi signifikansi $>0,05$, maka varian kelompok data adalah sama, jika signifikansi $<0,05$, maka varian kelompok tidak sama.

c. Uji Hipotesis

Uji hipotesis yang digunakan dalam penelitian ini adalah melalui program SPSS 16 dengan menggunakan computer, di mana uji hipotesis yang digunakan dalam program SPSS 16 tersebut adalah uji Independent Sample T Test untuk menguji signifikansi perbedaan mean dua kelompok data pada tarif signifikan $95 \%(\alpha=0,05)$.

Indikator pengaruh dari penerapan strategi Quantum Learning dalam penilaian ini adalah perbedaan nilai-nilai antara kelompok antara hasil pre-test dan data hasil post-test kelompok kontrol. Hasil post-test pada kelompok eksperimen lebih besar secara signifikasi daripada nilai hasil rata-rata hasil pretest pada kelompok eksperimen, maka penarapan strategi Quantum Learning juga dapat berpengaruh.

\section{HASIL DAN PEMBAHASAN}

Tempat penelitian yang dilaksanakan oleh peneliti adalah SMP Negeri 5 Wonomulyo yang memiliki luas pekarangan 8.045 $\mathrm{M}^{2}$ terletak di jalan poros Majene nomor 105 Kecamatan Wonomulyo Kabupaten Polewali Mandar. SMP Negeri 5 Wonomulyo memiliki 15 ruang kelas dan beberapa ruangan lainnya, seperti ruangan kepala sekolah, perpustakaan, komputer, tata usaha, BK, OSIS, UKS, dan 1 Laboratorium. Adapun jumlah tenaga pengajar di sekolah ini sebanyak 57, di antaranya guru tetap 34 orang, guru tidak tetap 12 orang, pegawai tetap 7 orang, dan pegawai tidak tetap 4 orang.

Kelas yang menjadi populasi penelitian ini adalah kelas VII, dan yang menjadi sampel dalam penelitian ini adalah kelas VII A dan VII B. Kelas VII A sebagai kelas eksperimen dan kelas VII B adalah kelas kontrol. Jumlah peserta didik kelas VII A adalah 29 orang, sedangkan jumlah peserta didik kelas VII B 27 orang. Pelaksanaan penelitian ini dilakukan 2 kali pertemuan dan dua kali tes, yaitu pre test dan post test.

a. Analisis Statistik Deskriptif Kelompok Kontrol

1. Analisis Statistik Deskriptif untuk Data Nilai Hasil Pre-Test Kelompok Kontrol

Hasil analisis data menunjukkan bahwa jumlah peserta didik sebanyak 27 orang memiliki nilai rata-rata sebesar 71.00 , yang mana nilai tengahnya 75 dan nilai yang paling banyak diraih oleh peserta didik adalah 75 . Standar Deviasi 1.20 rentang skor minimum dan maksimum yaitu 50, yang mana skor minimumnya sebesar 41 dari nilai terendah yang mungkin dicapai, yaitu 0 dan 
skor maksimumnya sebesar 91 dari nilai tertinggi yang mungkin dicapai, yaitu 100 .

Hasil nilai pre-test untuk kelas VII B menunjukkan bahwa peserta didik yang memperoleh nilai antara 25-58 yang dikategorikan sangat rendah, yaitu sebanyak 5 orang dengan persentase sebesar 18,5\%, sedangkan peserta didik yang memperoleh nilai antara 59-66 yang dikategorikan rendah yaitu sebanyak 6 orang dengan persentase $22,2 \%$, selanjutnya peserta didik yang memperoleh nilai 67-75 yang di kategorikan sedang yaitu sebanyak 10 orang dengan persentase $37 \%$, selanjutnya peserta didik yang memperoleh nilai $76-83$ yang dikategorikan tinggi yaitu sebanyak 4 dengan persentase $14,8 \%$ dan peserta didik yang memperoleh nilai 84-91 yaitu 2 orang dengan persentase 7,4\%.

Berdasarkan hasil pembelajaran menulis teks tanggapan deskriptif tersebut untuk kelas VII B SMP Negeri 5 Wonomulyo dapat disimpulkan bahwa hasil pembelajaran menulis teks tanggapan deskriptif yang diperoleh peserta didik kelas VII B SMP Negeri 5 Wonomulyo masih ada beberapa siswa yang memperoleh kategori sangat rendah 5 orang atau dengan persentase 18,5\%, sedangkan memperoleh tinggi sebanyak 14 orang dengan jumlah persentase $51,8 \%$, dan yang memperoleh kategori sangat tinggi sebanyak 2 orang dengan jumlah persentase $7,4 \%$.

Jika skor hasil belajar menulis teks tanggapan deskriptif peserta didik tersebut dikelompokkan dalam 5 kategori sesuai dengan acuan mengikuti prosedur yang telah ditetapkan, maka hasilnya adalah terdapat 2 orang atau sebesar $3,4 \%$ yang berada pada kategori nilai sangat tinggi, dalam kategori nilai tinggi terdapat 14 orang atau sebesar $51,8 \%$, kategori rendah sebanyak 6 orang atau sebesar $22,2 \%$ dan sangat rendah sebanyak 5 orang atau $18,5 \%$ dari 27 peserta didik dari skor ideal sebesar $100 \%$.

\section{Analisis Statistik Deskriptif untuk Data Nilai Hasil Post-test Kelompok \\ Kontrol}

Hasil analisis statistik deskriptif menunjukkan bahwa dengan jumlah peserta didik sebanyak 27 orang, mereka memiliki nilai rata-rata sebesar 76,03, dimana nilai tengahnya 77 dan nilai yang paling banyak diraih oleh peserta didik adalah 24,4. Standar Deviasi 4,94 rentang skor minimum dan maksimum yaitu 19, dimana skor minimumnya sebesar 64 dari nilai terendah yang mungkin dicapai, yaitu 0 dan skor maksimumnya sebesar 83 dari nilai tertinggi yang mungkin dicapai, yaitu 100.

Kemudian, distribusi frekuensi hasil belajar peserta didik adalah peserta didik yang memperoleh nilai antara 25 - 58 yang dikategorikan sangat rendah, yaitu tidak ada sedangkan peserta didik yang memperoleh nilai antara $59-66$ 
yang dikategorikan rendah yaitu sebanyak 2 orang dengan persentase $7,4 \%$, selanjutnya peserta didik yang memperoleh nilai 67 - 75 yang di kategorikan sedang yaitu sebanyak 9 orang dengan persentase $33,3 \%$, selanjutnya peserta didik yang memperoleh nilai 76-83 yang dikategorikan tinggi yaitu sebanyak 16 dengan persentase $59,2 \%$. Jadi dapat disimpulkan bahwa setelah proses belajar mengajar dilakukan, hasil menulis tanggapan deskriptif peserta didik kelas VII B berada pada kategori tinggi.

Jika skor hasil belajar menulis teks tanggapan deskriptif peserta didik tersebut dikelompokkan dalam 5 kategori sesuai dengan acuan mengikuti prosedur yang telah ditetapkan, maka terdapat 16 orang peserta didik atau sebesar 59,2\% yang berada pada kategori nilai tinggi, pada kategori sedang sebanyak 9 peserta didik atau sebesar $33,3 \%$, sedangkan pada kategori rendah sebanyak 2 orang atau sebesar $7,4 \%$ dari 27 peserta didik dari skor ideal sebesar $100 \%$.

b. Hasil Analisis Statistik Deskriptif Kelompok Eksperimen

1. Analisis Statistik Deskriptif untuk Data Nilai Hasil Pre-test kelompok Eksperimen

Hasil analisis statistik deskriptif menunjukkan bahwa dengan jumlah peserta didik sebanyak 29 orang, mereka memiliki nilai rata-rata sebesar 55, di mana nilai tengahnya 58 dan nilai yang paling banyak diraih oleh peserta didik adalah 33. Standar Deviasi 1,70 rentang skor minimum dan maksimum yaitu 50, di mana skor minimumnya sebesar 33 dari nilai terendah yang mungkin dicapai yaitu 0 dan skor maksimumnya sebesar 83 dari nilai tertinggi yang mungkin dicapai yaitu 100.

Kemudian, distribusi frekuensi hasil belajar peserta didik yang memperoleh nilai antara 25-58 yang dikategorikan sangat rendah, yaitu sebanyak 17 orang dengan persentase sebesar 58,6\%, sedangkan peserta didik yang memperoleh nilai antara 59-66 yang dikategorikan rendah yaitu sebanyak 5 orang dengan persentase $17,2 \%$, selanjutnya peserta didik yang memperoleh nilai 67-75 yang dikategorikan sedang, yaitu sebanyak 5 orang dengan persentase $17,2 \%$. Selanjutnya, peserta didik yang memperoleh nilai 76-83 yang dikategorikan tinggi yaitu sebanyak 2 dengan persentase $6,9 \%$.

Jika skor hasil belajar menulis teks tanggapan deskriptif peserta didik tersebut dikelompokkan dalam 5 kategori sesuai dengan acuan mengikuti prosedur yang telah ditetapkan maka terdapat 29 orang peserta didik yang mengikuti tes awal pelajaran pada pelaksanaan tes awal (pre-test). Terdapat 2 orang atau sebesar $6,9 \%$ yang berada pada kategori nilai tinggi, pada kategori sedang sebanyak 5 orang atau sebesar $17,2 \%$ sedangkan pada kategori rendah 
sebanyak 5 orang atau sebesar $17,2 \%$ dan sangat rendah sebanyak 17 orang atau $58,6 \%$ dari 29 peserta didik dari skor ideal sebesar $100 \%$.

\section{Analisis Statistik Deskriptif untuk Data Nilai Hasil Post-test Kelompok} Eksperimen

Hasil analisis statistik deskriptif menunjukkan bahwa dengan jumlah peserta didik sebanyak 29 orang, mereka memiliki nilai rata-rata sebesar 79,37 dimana nilai tengahnya 80 dan nilai yang paling banyak diraih oleh peserta didik adalah 84. Standar Deviasi 7,07 rentang skor minimum dan maksimum yaitu 28, dimana skor minimumnya sebesar 68 dari nilai terendah yang mungkin dicapai yaitu 0 dan skor maksimumnya sebesar 96 dari nilai tertinggi yang mungkin dicapai yaitu 100 .

Distribusi frekuensi hasil belajar peserta didik yang memperoleh nilai antara 25-58 yang dikategorikan sangat rendah yaitu tidak ada sedangkan peserta didik yang memperoleh nilai antara 59 - 66 yang dikategorikan rendah yaitu tidak ada, selanjutnya peserta didik yang memperoleh nilai 67 - 75 yang di kategorikan sedang yaitu sebanyak 8 orang dengan persentase 27,5\%, selanjutnya peserta didik yang memperoleh nilai 76-83 yang dikategorikan tinggi yaitu sebanyak 10 dengan persentase $34,4 \%$ selanjutnya peserta didik yang dikategorikan sangat tinggi 11 orang dengan persentase $41,2 \%$. Jadi dapat disimpulkan bahwa setelah proses belajar mengajar dilakukan, hasil menulis teks tanggapan deskriptif peserta didik kelas VII A berada pada kategori tinggi.

Jika skor hasil belajar menulis teks tanggapan deskriptif peserta didik tersebut dikelompokkan dalam 5 kategori sesuai dengan acuan mengikuti prosedur yang telah ditetapkan terdapat 29 orang, 11 peserta didik atau sebesar $41,2 \%$ yang berada pada kategori nilai sangat tinggi, 10 orang peserta didik atau sebesar 34,4\% yang berada pada kategori nilai tinggi dan terdapat 8 orang atau sebesar $27,5 \%$ dari 29 peserta didik dari skor ideal sebesar $100 \%$.

\section{c. Hasil Analisis Statistik Inferensial}

\section{Uji Normalitas}

Adapun kriteria penerimaan bahwa suatu data berdistribusi normal atau tidak adalah sebagai berikut.

- Jika signifikansi $<0,05$, maka data tidak berdistribusi normal

- Jika signifikansi $>0,05$, maka data berdistribusi normal

a. Uji Normalitas Data Pre-test kelas eksperimen

Hasil analisis uji normalitas diperoleh bahwa data hasil pre-test kelas eksperimen diperoleh nilai Asymp. Sig (2-tailed) dengan nilai 0,306. Artinya nilai Sig $>0,05$, karena nilai Sig 0,306 lebih besar dari pada Sig 0,05. Maka dapat 
disimpulkan bahwa $\mathrm{H}_{0}$ diterima dan menolak $\mathrm{H}_{1}$, artinya data pre-test kelas eksperimen berdistribusi normal.

b. Uji Normalitas Data post-test kelas eksperimen

Hasil output SPSS (Statistical Package For Social Sience) versi 16,0 for windows dimana uji hipotesis yang digunakan adalah kolmogorov-smirnov. Untuk data hasil post-test kelas eksperimen diperoleh nilia asymp. Sig (2-tailed)dengan nilai 0,694 artinya Sig > 0,05, karena nilai Sig 0,694 lebih besar dari pada Sig 0,05 . Maka dapat disimpulkan bahwa $\mathbf{H}_{0}$ diterima dan menolak $\mathbf{H}_{1}$ artinya data post-test kelas eksperimen berdistribusi normal.

c. Uji Normalitas Data Pre-Test Kelas Kontrol

Untuk data hasil pre-test kelas kontrol diperoleh nilai asymp. Sig (2tailed)dengan nilai 0,139 artinya Sig $>0,05$, karena nilai Sig 0,139 lebih besar dari pada Sig 0,05. Maka dapat disimpulkan bahwa $\mathrm{H}_{0}$ diterima dan menolak $\mathrm{H}_{1}$ artinya data pre-test kelas kontrol berdistribusi normal.

d. Uji Normalitas Data Post-Test Kelas Kontrol

Untuk data hasil pre-test kelas kontrol diperoleh nilai asymp. Sig (2tailed)dengan nilai 0,107 artinya Sig $>0,05$, karena nilai Sig 0,107 lebih besar dari pada Sig 0,05. Maka dapat disimpulkan bahwa $\mathrm{H}_{0}$ diterima dan menolak $\mathrm{H}_{1}$ artinya data pre-test kelas kontrol berdistribusi normal.

\section{Uji Homogenitas Varians}

Pada penelitian ini uji hipotesis yang digunakan adalah Compare Means

One Way Anova atau uji F. Adapun hipotesis statistik dalam pengujian ini adalah sebagai berikut.

a. Merumuskan Hipotesis

$\mathrm{H}_{0}$ : Variansi dua kelompok data Homogen

$\mathrm{H}_{1}$ : Variansi dua kelompok tidak Homogen

b. Menentukan $\mathbf{F}_{\text {tabel }}$ pada tingkat signifikansi 0,05 dan df $1=$ jumlah kelompok data -1 dan df $2=n-2$ ( $n$ dalam hal ini jumlah data hasil tes dan 2 adalah jumlah kelompok

c. Kriteria pengujian

- Jika $f_{\text {hitung }}>\mathrm{f}_{\text {tabel}}$, maka $\mathrm{H}_{0}$ ditolak.

- Jika $\mathrm{f}_{\text {hitung }} \leq \mathrm{f}_{\text {tabel, }}$ maka $\mathrm{H}_{0}$ diterima

Berdasarkan signifikansi

- Jika signifikansi $<0,05$ maka $\mathrm{H}_{0}$ ditolak

- Jika signifikansi $>0,05$ maka $\mathrm{H}_{0}$ diterima

Hasil uji homogenitas Pre-test kontrol-Pre-test eksperimen diperoleh bahwa nilai $\mathrm{F}_{\text {hitung }}=2.146 \mathrm{df} 1=5$, df $2=20$ dan signifikansi didapat 0,093 . Dari tingkat signifikansi 0,05 diperoleh $F_{\text {tabel }}=2,710$ sehingga $F_{\text {hitung }}=2.146 \leq$ 
$F_{\text {tabel }} 2,710$ dan signifikansi $0,093>0,05$, maka diketahui bahwa kedua data memiliki variansi yang homogen.

Selanjutnya, hasil uji Homogenitas Post-tes kontrol- Post-tes eksperimen diperoleh bahwa nilai $\mathrm{F}_{\text {hitung }}=0,768 \mathrm{df} 1=5$, df $2=16$ dan signifikansi didapat 0,606. Dari tingkat signifikansi 0,05 diperoleh $F_{\text {tabel }}=2,352$ sehingga $F_{\text {hitung }}=$ $0,768 \leq \mathrm{F}_{\text {tabel }} 2,352$ dan signifikansi $0,606>0,05$, maka diketahui bahwa kedua data memiliki variansi yang homogen.

\section{Pengujian Hipotesis}

Pada penelitian ini, uji hipotesis yang digunakan adalah Compare Means Independent Sampel T Test menggunakan Equal Variansassumed. Pengujian menggunakan tingkat signifikansi 0,05 atau tingkat kepercayaan (confidence interval) sebesar $95 \%$.

Hasil pengolahan data melalui program SPSS (Statistical Package For Social Sience) versi 16,0 for windows diperoleh data hasil post-tes kedua kelompok dimana nilai $t_{\text {hitung }}$ pada equal variances assumed $=2,034 \mathrm{df}=54$, dan diperoleh $t_{\text {tabel }}=2,004$ sehingga $t_{\text {hitung }}=2,034>t_{\text {tabel }}=2,004$ dan signifikansi $0,004<0,05$. Maka $\mathrm{H}_{0}$ ditolak dan $\mathrm{H}_{1}$ diterima yaitu strategi quantum learning berpengaruh terhadap hasil belajar peserta didik kelas VII SMP Negeri 5 Wonomulyo.

Dari hasil penelitian tersebut, hipotesis dalam penelitian ini diterima karena pembelajaran menggunakan strategi Quantum Learning lebih efektif digunakan dibandingkan dengan menggunakan pembelajaran konvensional terhadap kemampuan menulis teks tanggapan deskriptif peserta didik kelas VII SMP Negeri 5 Wonomulyo.

Berdasarkan analisis data yang telah dijabarkan, maka disimpulkan penggunaan Strategi Quantum Learning efektif terhadap kemampuan menulis teks tanggapan deskriptif pada peserta didik kelas VII SMP Negeri 5 Wonomulyo Kabupaten Polewali Mandar. Hasil penelitian tersebut menunjukkan bahwa, pada kelas eksperimen (VII A) memiliki nilai rata - rata Pre-test sebesar nilai rata-rata 55,37, median 58 mode 33 Standar Deviasi 1,70, rentang skor minimum dan maksimum yaitu 50, di mana skor minimumnya sebesar 33 dan skor maksimumnya sebesar 83. Sedangkan kelas kontrol (VII B) memiliki nilai rata-rata Pre-tes sebesar 71,00, median 75, mode 75, Standar Deviasi 1,20, rentang skor 50, di mana skor minimumnya sebesar 41 dan skor maksimumnya sebesar 91.

Kemudian, hasil Post-test untuk kelas eksperimen peserta didik memiliki nilai rata-rata sebesar 79,37, median 80 , mode 84, Standar Deviasi 7,07, rentang skor minimum dan maksimum yaitu 21, di mana skor minimumnya sebesar 68 dan maksimumnya sebesar 96 . Sedangkan pada kelas kontrol memiliki nilai rata- 
rata sebesar 76,03, median 77, mode 80, Standar Deviasi 4,94, rentang skor minimum dan maksimum yaitu 19, di mana skor minimumnya sebesar 64 dan skor maksimumnya sebesar 83.

Berdasarkan hasil uji-t yang telah dilakukan oleh peneliti dapat diketahui bagaimana pengaruh penggunaan strategi Quantum Learning terhadap kemampuan menulis teks tanggapan deskriptif. Peneliti menggunakan bantuan aplikasi SPSS (Statistical Package and Social Siences)versi 16,0 for windows. Untuk hasil post-tes kedua kelompok data diperoleh $t_{\text {hiting }}$ pada equal variances assumed $=2,034 \mathrm{df}=54$, dan diperoleh $\mathrm{t}_{\text {tabel }}=2,004$ sehingga $\mathrm{t}_{\text {hitung }}=2,034>\mathrm{t}_{\text {tabel }}$ $=2,004 .<0,05$ equal variance assumed $=3,530, \mathrm{df}=59$, dan diperoleh $\mathrm{t}_{\text {tabel }}=$ 2,001. Dari hasil yang diperoleh tersebut dapat dinyatakan bahwa penggunaan Strategi Quantum Learning efektif terhadap menulis teks tanggapan deskriptif peserta didik kelas VII SMP Negeri 5 Wonomulyo Kabupaten Polewali Mandar.

Efektifnya strategi tersebut karena memiliki beberapa karakteristik yang sesuai dengan pokok bahasan dalam penelitian ini, yaitu berpangkat pada psikologi kognitif, lebih manusiawi, individu menjadi pusat perhatian, potensi diri, kemampuan berpikir, motivasi sebagainya diyakini dapat berkembang secara maksimal, lebih bersifat konstruktif namun juga menekankan pentingnya peranan lingkungan pembelajaran yang efektif dan optimal dalam pencapaian tujuan pembelajaran, menyinergikan faktor potensi individu dengan lingkungan pandangan Quantum, faktor lingkungan dan kemampuan memiliki posisi yang sama-sama penting, dan memaksudkan perhatian pada interaksi yang bermutu dan bermakna, bukan sekedar transaksi makna.

\section{SIMPULAN}

Hasil penelitian yang membuktikan bahwa strategi quantum learning layak digunakan dalam pembelajaran menulis teks tanggapan deskriptif pada peserta didik kelas VII SMP Negeri 5 Wonomulyo Kabupaten Polewali Mandar. Hal ini didukung dengan hasil persentase yang membuktikan bahwa angka yang dihasilkan rata-rata mencapai $80-90 \%$ keaktifan dan partisipasi peserta didik dalam mengikuti proses pembelajaran. Tentu hasil observasi ini linear dengan hasil post-tes yang dilakukan oleh peneliti, bahwa signifikansi pengaruh strategi Quantum Learning terhadap peningkatan menulis teks tanggapan deskriptif peserta didik sangat tinggi. 


\section{SARAN DAN REKOMENDASI}

Adapun saran dari hasil penelitian ini, yaitu:

1. kepada institusi sekolah dan para pendidik agar menggunakan strategi quantum learning dalam pembelajaran di kelas karena sudah terbukti keefektifannya.

2. Kepada peneliti selanjutnya dapat mengembangkan penelitian ini dengan mengkaji pembelajaran dengan strategi quantum learning lebih mendalam lagi.

\section{DAFTAR PUSTAKA}

Alek dan Achmad H.P. (2010). Bahasa Indonesia untuk Perguruan Tinggi. Jakarta: Kencana Prenada Media Group.

Budiman. (2009). Analisis Teks Media. Bandung: Rosda.

Dalman, (2014). Keterampilan Menulis. Jakarta: Raja Grafindo Persada.

Depdikbud. (2008). Kamus Besar Bahasa Indonesia. Edisi keempat. Jakarta:Balai Pustaka.

De Porter, Hernacki. (2009). Quantum Learning: membiasakan belajar nyaman dan Menyenangkan. Bandung: Kaifa.

Halliday, M.A.K. (1994). An Introduction to Functional Grammar. London: Edward Arnold.

Kemendikbud. (2013). Buku Guru Bahasa Indonesia: Ekspresi Diri dan Akademik. Jakarta: Kementerian Pendidikan dan Kebudayaan.

Keraf, Gorys. (1982). Eksposisi dan Deskripsi. Ende-Flores:Nusa Indah.

Mudini dan Salamat Purba. (2009). Pembelajaran Berbicara. Jakarta: Departemen Pendidikan Nasional Direktorat Peningkatan Mutu Pendidik dan Tenaga Kependidikan Pusat Pengembangan dan Pemberdayaan Pendidik dan Tenaga Kependidikan Bahasa.

Saud. (2010). Inovasi Pendidikan. Bandung: Alfabeta.

Salam. 2009. Pendidikan Penulisan Kreatif. Makassar: Badan Penerbit Universitas Negeri Makassar.

Tarigan, Hendry Guntur. (2008). Menulis. Bandung: Angkasa.

Trianto. (2007). Model-model Pembelajaran Inovatif Berorientasi Kontruktivistik. Prestasi Pustaka: Jakarta.

Trianto. (2010). Mengembangkan Model Pembelajaran Tematik. Jakarta: PT Prestasi Pustaka

Zainurrahman. (2011). Menulis: dari teori hingga praktek. Bandung: Alfabeta. 